\title{
HIV AND DEMENTIA: PREVALENCE AND RISK FACTORS
}

\author{
HIV e demência: prevalência e fatores de risco \\ VIH y demencia: prevalencia y factores de riesgo
}

Original Article

\begin{abstract}
Objective: To determine the prevalence of patients at risk of developing HIV-associated neurocognitive disorder (HAND) and identify factors possibly associated with its occurence. Methods: Quantitative cross-sectional study conducted at the Specialized Care Service (Serviço de Atendimento Especializado - SAE) for HIV/Aids of the Integrated Medical Care Center (Núcleo de Atendimento Médico Integrado - NAMI) of the University of Fortaleza (Universidade de Fortaleza - UNIFOR), Fortaleza, Ceará, Brazil. We reviewed medical records of all 249 patients that started medical follow-up at SAE/NAMI since its foundation (August/2010) until January/2014, including in the analysis those who completed the international HIV dementia scale - IHDS during routine medical visits. Epidemiological, clinical and laboratory variables were collected in addition to IHDS score and the sample was classified in two groups: patients with IHDS $\geq 10$ (Group 1) and IHDS $<10$ (Group 2). Chisquared test was used for categorical variables and student $t$ test, mann whitney test and linear regression were used for numerical variables. Results: The study population consisted of 178 patients with mean IHDS score of $9.5(+/-1.6)$. HAND prevalence was $41.6 \%(74 / 178)$ (IHDS $<10)$. These patients presented older mean age $(37.4$ years) and longer mean time from HIV diagnosis to medical follow-up than the others (10.1 months) when compared to Group 2 (31 years old and 4.6 months, respectively), suggesting that these two variables were possibly associated with HAND occurrence. Conclusion: The IHDS application showed a high prevalence of HAND in the study population. More advanced age and longer time from HIV diagnosis to medical follow-up are possibly associated with its occurence.
\end{abstract}

Descriptors: AIDS Dementia Complex; Acquired Immunodeficiency Syndrome; Neurocognitive Disorders.

\section{RESUMO}

Objetivo: Determinar a prevalência de pacientes sob risco de desenvolver desordem cognitiva relacionada ao HIV (HAND - HIV associated neurocognitive disorder) $e$ identificar fatores que possivelmente estariam associados à sua ocorrência. Métodos: Estudo quantitativo, transversal, conduzido no Serviço de Atendimento Especializado (SAE) em HIVIAIDS do Núcleo de Atenção Médica Integrada (NAMI), Universidade de Fortaleza (UNIFOR), Fortaleza/Ceará/Brazil. Foram revisados todos os 249 prontuários de pacientes que iniciaram acompanhamento no SAE/NAMI desde a sua criação (agosto/2010) até janeiro/2014, incluindo-se na análise aqueles que apresentavam o registro da aplicação da escala de demência do HIV (IHDS - international HIV dementia scale) nas consultas de rotina. Coletaram-se variáveis epidemiológicas, clínicas e laboratoriais, além do valor do IHDS, classificando-se a amostra em dois grupos: pacientes com IHDS $\geq 10$ (Grupo 1) e IHDS<10 (Grupo 2). Utilizaram-se testes Qui-quadrado para variáveis categóricas, e $T$ de Student, Mann Whitney e regressão linear para variáveis numéricas. Resultados: A população do estudo consistiu em 178 pacientes, com escore médio da IHDS de 9.5 (+/1.6). A prevalência de HAND foi de 41,6\% (74/178) (IHDS<10). Nesses pacientes, a idade média era mais elevada (37,4 anos) e o intervalo médio de tempo entre o diagnóstico do HIV e o início do acompanhamento era maior que os demais (10,1 meses), quando comparados com o Grupo 2 (31 anos e 4,6 meses respectivamente), sugerindo que essas duas variáveis possivelmente estavam associadas com a ocorrência da HAND. Conclusão: A utilização do IHDS demonstrou uma elevada prevalência de HAND na população estudada. A idade mais elevada e o intervalo de tempo maior entre o diagnóstico do HIV e o início

\author{
Lara Gurgel Fernandes \\ Távora $^{(1,2)}$ \\ Thais Martins Figueiredo ${ }^{(1)}$ \\ Ramille Moitas Krammer de \\ Mesquita $^{(1)}$ \\ Fernando Ricarte Bezerra ${ }^{(1)}$ \\ Bruno Pinheiro Aquino ${ }^{(1)}$ \\ Jeová Keny de Baima Colares ${ }^{(1,2)}$
}

1) University of Fortaleza (Universidade de Fortaleza - UNIFOR) - Fortaleza (CE) - Brazil

2) São José Infectious Diseases Hospital (Hospital São José de Doenças Infecciosas $H S J)$ - Fortaleza (CE) - Brazil
Received on: 03/15/2016

Revised on: 04/06/2016

Accepted on: 06/20/2016 
do acompanhamento estão possivelmente relacionados com essa ocorrência.

Descritores: Complexo AIDS Demência; Síndrome da Imunodeficiência Adquirida; Transtornos Neurocognitivos.

\section{RESUMEN}

Objetivo: Determinar la prevalencia de pacientes con riesgo para el desarrollo del desorden cognitivo relacionado al VIH (HAND - HIV associated neurocognitive disorder) y identificar los factores que posiblemente estarían asociados a su ocurencia. Métodos: Estudio cuantitativo, transversal realizado en el Servicio de Atención Especializada (SAE) en VIH/SIDA del Núcleo de Atención Médica Integrada (NAMI), Universidad de Fortaleza (UNIFOR), Fortaleza/Ceará/Brasil. Se revisó todos los 249 historiales clínicos de pacientes que iniciaron seguimiento en el SAE/NAMI desde su creación (agosto/2010) hasta enero/2014, incluyéndose en el analisis aquellos que presentabam el registro de la aplicación de la escala de demencia del VIH (IHDS international HIV dementia scale) en las consultas de rutina. Se recogieron variables epidemiológicas, clinicas y de laboratorio además del valor del IHDS clasificando la muestra en dos grupos: pacientes con IHDS $\geq 10$ (Grupo 1) y IHDS<10 (Grupo 2). Se utilizó las pruebas Chi-cuadrado para las variables categoricas y la prueba T de Student, Mann Whitney y regresión linear para las variables numericas. Resultados: La población del estudio fue de 178 pacientes con puntuación media para la IHDS de 9.5 (+/1.6). La prevalencia de HAND fue del 41,6\% (74/178) (IHDS<10). En eses pacientes la edad media fue más elevada (37,4 años) y el intervalo de tiempo medio entre el diagnostico del VIH y el inicio del seguimiento fue mayor que los demás (10,1 meses) al comparar con el Grupo 2 (31 años y 4,6 meses respectivamente) lo que sugiere que esas dos variables posiblemente estaban asociadas a la ocurrencia de la HAND. Conclusión: La utilización del IHDS demonstró una elevada prevalencia de HAND en la población estudiada. La edad más elevada y el intervalo de tiempo mayor entre el diagnostico del VIH y el inicio del seguimiento están posiblemente relacionados con esta ocurrencia.

Descriptores: Complejo SIDA Demencia; Síndrome de Inmunodeficiencia Adquirida; Trastornos Neurocognitivos.

\section{INTRODUCTION}

The WHO estimates that almost 78 million people have been infected with HIV since the begining of this epidemic ${ }^{(1)}$. According to the 2014 report from the Brazilian Department of STD/Aids and Viral Hepatites (Departamento de DST, Aids e Hepatites Virais - DDAHV), 734 thousand people were living with HIV/Aids (PLHA) in the country, representing a $0.4 \%$ prevalence rate ${ }^{(2)}$.

Once it enters the human organism, HIV infects many immune system cells, such as $\mathrm{CD}_{4}+\mathrm{T}$ Lymphocytes $\left(\mathrm{TLCD}_{4}+\right)$ and macrophages. Some of these infected cells are located in the central nervous system (CNS) (astrocytes, microglia) ${ }^{(3)}$. Clinical manifestations of this viral neurotropism are diverse since any level of the neuroaxis can be involved ${ }^{(4,5)}$. Diseases secondary to this direct invasion of HIV into the CNS are called HIV-associated neurocognitive disorders (HANDs) and can be classified as: asymptomatic neurocognitive impairment (ANI), mild neurocognitive disorder (MND) and HIV-associated dementia (HAD) ${ }^{(5)}$.

Dementia is a common neurological complication of Aids and is manifested by approximately $20 \%$ of HIV+ patients $^{(6)}$. Among untreated Aids patients, up to $25 \%$ may develop severe symptoms of dementia ${ }^{(7)}$. Despite the advent of the highly active antirretroviral therapy (HAART), which reduced the incidence of many HIV-associated disorders, HAD is still common and, in many cases, interferes with antirretroviral adherence, reduces quality of life and increases morbidity and mortality from HIV infection ${ }^{(4,8)}$.

The diagnosis of dementia is sometimes difficult and based on clinical examination only. Neurological screening tests, such as the Mini Mental State Examination (MMSE), are essential tools for enhancing the diagnosis accuracy, particularly in initial dementia ${ }^{(9,10)}$. However, the MMSE was designed to the screening of cortical dementias and is therefore less accurate in detecting subcortical dementia such as $\mathrm{HAD}^{(11)}$. The International HIV Dementia Scale (IHDS) is a simple and quick test that assesses cognitive functions of memory, attention and fine motor function in HIV+ individuals ${ }^{(12)}$. In addition to its easy application, the IHDS also has a satisfactory sensitivity and specificity for HAND detection: $78.5 \%$ and $80 \%$ respectively ${ }^{(13)}$.

In a longitudinal study comparing the risk of developing symptomatic decline between $\mathrm{HIV}+$ people who at baseline were neurocognitively normal $(\mathrm{NCN})$ vs those with ANI, the authors demonstrated that ANI conveys a 2 to 6-fold increase in risk for earlier development of symptomatic HAND, supporting the prognostic value of the ANI diagnosis in clinical settings ${ }^{(14)}$. Thus, the early identification of incipient HAND is important as it can guide healthcare profissionals to promptly intervene and protect patients from the irreversible changes in the CNS, helping them to mantain the highest possible level of skills and independence ${ }^{(15)}$. Also, the knowledge of possible related factors may significantly contribute to the establishment of prevention strategies against HAND development.

The aim of this study was to determine the prevalence of patients at risk for developing dementia, using the IHDS, and identify factors possibly associated with its occurrence in a reference center in Northeastern Brazil.

\section{METHODS}

This is a cross-sectional study and data were collected from the review of $249 \mathrm{HIV}+$ adult patients' medical records 
from January 2013 to January 2014. All the patients were receiving medical follow-up at the Integrated Medical Care Center (Núcleo de Atenção Médica Integrada - NAMI), a reference university center for the treatment of HIV/Aids in Fortaleza, Ceará, located in Northeastern Brazil.

Inclusion criteria were patients $>18$ years of age and having the IHDS (International HIV Dementia Scale) score registered on the medical record. After this initial review, 186 patients were selected to have their data included in the study.

Exclusion criteria were current or past history of opportunistic infection of the CNS (Central Nervous System), psychiatric or neurological disorders that could alter the IHDS result and the diagnosis of dementia secondary to other causes.

The collected variables were: age, gender, time from HIV diagnosis to medical follow-up, $\mathrm{TLCD}_{4}+$ count and HIV viral load (in the beginning of medical follow-up, at time of HAART (Highly Active Antiretroviral Therapy) initiation and when IHDS was performed), the occurrence of opportunistic infections, use of antirretroviral therapy, tobacco, alcohol and ilicit drug use, comorbidities (arterial hypertension, diabetes mellitus) and IHDS score.

Patients were classified according to the IHDS score. Those with IHDS $\geq 10$ were considered without neurocognitive disorder (Group 1). Group 2 consisted of those patientes with IHDS $<10$, and, for this reason, they were considered with possible dementia/ neurocognitive deficit ${ }^{(11)}$.

A specific instrument was designed for data collection. All data collected by the researchers were reviewed by one of the study supervisors, which is a specialist in HIV/ Aids patients' care. After this review, data were inserted in the study database, which was developed using the Epidata software, version 3.0, and were analyzed using STATA software. Chi-squared test was used for categorical variables analysis. Numerical variables were analyzed using simple linear regression, student $\mathrm{T}$ test (for those with normal distribution) and mann-whitney test. A $p$ value of $<0.05$ was considered significant.

Approval for this study was obtained from the Ethics Committee (Comitê de ética - COÉTICA) of the University of Fortaleza (Opinion No. 323.473/2013) and NAMI/ UNIFOR management board.

\section{RESULTS}

The study population consisted of 186 patients, 8 of whom were excluded due to CNS infection diagnosis: 3 neurotoxoplasmosis, 2 neurosyphilis and 1 neurocryptococcosis (Figure 1).

Of the remaining 178 patients, $41.6 \%$ (74) had IHDS $<10$ (group 2) and $85.3 \%$ (152) were men. The mean IHDS score was $9.5( \pm 1.6)$. No difference was found when comparing past or current use of alcohol, tobacco or illicit drugs in both groups. Likewise, the occurrence of comorbidities and Hepatitis B or C co-infection were similar in both groups (Table I).

The mean age was 34 years old - mean of 31 years old ( \pm 9 years) for patients in group 1 and 37.4 years old ( \pm 10 years) for those in group $2(p<0.001)$. The mean time from HIV diagnosis to medical follow-up was 7 months, with patients in group 1 presenting, in general, a shorter mean time interval (4 months) when compared to group 2 (10 months) $(p=0.04)$. These and other data analyses are presented in Table I.

The linear correlation analysis showed an inverted correlation between patients' age and the IHDS score, suggesting that the older the patient, the lower the IHDS score. $\left(\mathrm{R}^{2}:-0.4 ; p<0.001\right)$. The analysis of the other numerical variables showed no significant linear correlation to the IHDS score (Table II).

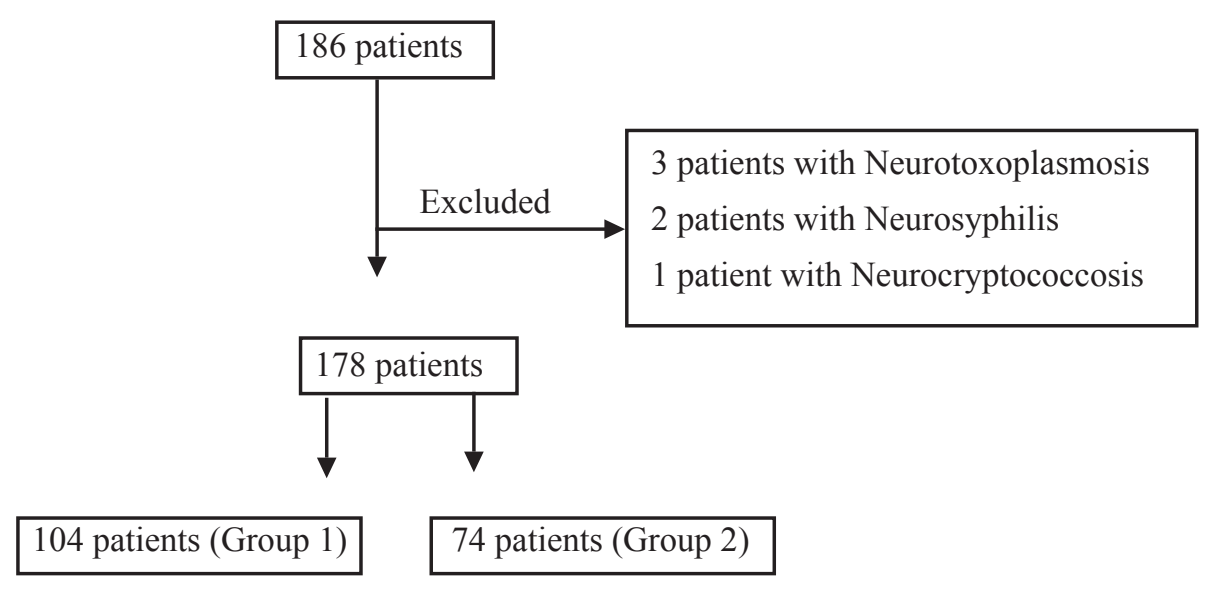

Figure 1 - Sample selection and classification of cognitive impairment in HIV+ adult patients. Fortaleza, Ceará, 2010-2014. 
Table I - Risk factors for HIV associated dementia in Northeastern Brazil - univariate analysis. Fortaleza, Ceará, 2010-2014.

\begin{tabular}{|c|c|c|c|}
\hline \multirow[b]{2}{*}{ Variables } & \multicolumn{3}{|c|}{ International HIV Dementia Scale (IHDS) } \\
\hline & $\begin{array}{c}\text { IHDS } \geq 10 \\
\text { n (\%) }\end{array}$ & $\begin{array}{c}\text { IHDS }<10 \\
\text { n (\%) }\end{array}$ & p-value \\
\hline \multirow{3}{*}{$\begin{array}{l}\text { Mean age (years) } \pm \text { SD } \\
\text { Mean time from HIV diagnosis to medical follow-up } \\
\text { (months) } \pm \mathrm{SD} \\
\text { Mean initial } \mathrm{TLCD}_{4}+(\text { cells } / \mathrm{dl}) \pm \mathrm{SD}\end{array}$} & $31.0 \pm 9.00$ & $37.4 \pm 10.00$ & $<0.001$ \\
\hline & $4.6 \pm 0.80$ & $10.1 \pm 3.50$ & 0.04 \\
\hline & $428 \pm 28$ & $410 \pm 31$ & 0.33 \\
\hline Mean HIV viral load (copies/ml) \pm SD & $112.9 \pm 56.78$ & $194.0 \pm 155.90$ & 0.29 \\
\hline \\
\hline Men & $92(51.6)$ & $60(33.7)$ & 0.16 \\
\hline Women & $12(6.7)$ & $14(7.9)$ & \\
\hline Tobacco use & $21(20.2)$ & $13(17.6)$ & 0.62 \\
\hline Alcohol use & $45(43.3)$ & $25(33.8)$ & 0.44 \\
\hline Illicit drugs use & $12(11.5)$ & $2(2.7)$ & 0.09 \\
\hline Diabetes & $15(14.4)$ & $13(12.5)$ & 0.57 \\
\hline Hypertension & $5(4.8)$ & $7(9.4)$ & 0.22 \\
\hline Hypercholesterolemia & $21(20.2)$ & $16(21.6)$ & 0.81 \\
\hline Hypertrigliceridemia & $30(28.8)$ & $23(31.0)$ & 0.74 \\
\hline Previous Hepatitis B & $16(15.4)$ & $16(21.6)$ & 0.28 \\
\hline HIV/HBV Co-infection & $3(2.8)$ & $1(0.9)$ & 0.49 \\
\hline Previous Hepatitis C & $1(0.9)$ & $3(4.0)$ & 0.17 \\
\hline HIV/HCV Co-infection & $1(0.9)$ & - & 0.39 \\
\hline Aids defining condition on $1^{\text {st }}$ medical visit & $10(9.6)$ & $8(10.8)$ & 0.79 \\
\hline \multicolumn{4}{|l|}{ TLCD + on IHDS application } \\
\hline$<350$ cells $/ \mathrm{dl}$ & $29(27.9)$ & $25(33.8)$ & 0.39 \\
\hline$\geq 350$ cells/dl & $75(72.1)$ & $49(66.2)$ & 0.39 \\
\hline \multicolumn{4}{|l|}{ HIV viral load on IHDS application } \\
\hline$\geq 100,000$ copies $/ \mathrm{ml}$ & $61(58.6)$ & $40(54.0)$ & 0.54 \\
\hline$<100,000$ copies $/ \mathrm{ml}$ & $43(41.3)$ & $34(45.9)$ & 0.54 \\
\hline HAART use & $92(88.5)$ & $68(91.2)$ & 0.45 \\
\hline Total & $104(58.4)$ & $74(41.6)$ & \\
\hline
\end{tabular}

HIV: Human Immunodeficiency Virus. IHDS: International HIV Dementia Scale.

$\mathrm{TLCD}_{4}+$ : CD4+ Lymphocytes. SD: Standard Deviation. HAART: Highly Active Antirretroviral Therapy.

Table II - Risk factors for HIV associated dementia in Northeastern Brazil- Linear correlation analysis. Fortaleza, Ceará, 2010-2014.

\begin{tabular}{lcc}
\hline Variables & $\mathbf{r}^{2}$ & $p$ value \\
\hline Age (years) & -0.40 & $<0.001$ \\
Time from HIV diagnosis to medical follow-up (months) & -0.03 & 0.62 \\
Initial TLCD + (cells/dl) & 0.10 & 0.19 \\
TLCD $_{4}+$ on IHDS application (cells/dl) & 0.01 & 0.83 \\
Initial HIV viral load (copies/ml) & -0.04 & 0.95 \\
HIV viral load on IHDS application (copies/ml) & 0.01 & 0.90 \\
\hline
\end{tabular}

HIV: Human Immunodeficiency Virus. TLCD + : CD4+ Lymphocytes. IHDS: International HIV Dementia Scale 


\section{DISCUSSION}

The IHDS results in the present study suggested that $41.6 \%$ of the patients had some degree of neurocognitive disorder. This prevalence could be considered high when compared to other already published data, which showed a prevalence of $20 \%$ of this disorder ${ }^{(6)}$. However, some Brazilian authors have shown a higher prevalence (36-50\%) of HAND using the IHDS, which corroborates the finding of the present study ${ }^{(10,13)}$. This prevalence variation could possibly be secondary to the different occurence of many factors associated with HANDs in each region ${ }^{(3)}$.

In the present study, the mean age of Group 2 was 37.4 years old ( \pm 10 years) while in Group 1 it was 31 years old ( \pm 9 years) $(p<0.001)$, suggesting that age is possibly associated with the HAND occurrence in HIV+ patients. In accordance with this finding, some studies have shown that age is an important vulnerability factor for the development of HIV-assocuated neuronal injury. Older HIV+ patients are at a higher risk of developing HAND when compared to younger individuals ${ }^{(16,17)}$.

No difference regarding HIV mean viral load was found in the present study when comparing the two groups. In addition, there was no correlation between HIV viral load and IHDS score in the linear correlation model. Although it seems reasonable to think that a high HIV viral load would be associated with HAND occurrence, as the direct HIV neurotoxic effects on CNS macrophages is one of the proposed mechanisms for this entity ${ }^{(18)}$, many authors have found similar results ${ }^{(15,19-21)}$. These findings raise at least two important issues.

The first one is that HIV viral load in the CNS might be more important in HAND pathogenesis than the peripheral blood HIV levels. It is not uncommon to find detectable HIV viral load in the cerebrospinal fluid (CSF) in patients with undetectable HIV RNA in peripheral blood samples, a situation known as CSF scape. In a study conducted in Italy, CSF scape was found in $28.6 \%$ of the 84 participants with HIV RNA $<50$ copies/ $/ \mathrm{mL}^{(22)}$. The authors suggest that this finding could explain the persistence of neuronal degererative changes in patients with HIV viral load completely suppressed. The Italian research group also presented different CSF penetration quotients of the antiretroviral drugs used to treat those patients. Patients whose HAART showed a lower CSF penetration quotient were more likely to have CSF scape. In addition, the limited distribution of antiretroviral drugs was associated with persisting HAND among effectively treated HIV+ individuals (i.e., with suppressed plasma viral loads) in another study ${ }^{(4)}$. Also, a postmortem neuropathology study using data from 90 human immunedeficiency virus- infected patients found a strong correlation between CSF HIV viral load and neurodegeneration ${ }^{(23)}$. All these studies reinforce the hypothesis that HIV neuronal degeneration is more likely to occur in the detectable CSF HIV viral load scenario instead of being a peripheral HIV viral load dependent phenomenon.

The second important issue is that persistent immune activation might contribute to neurodegeneration and cognitive impairment. Recent work suggests that the stage for HIV neuropathogenesis may be set with initial viral entry into the CNS, followed by initiation of pathogenetic processes such as neuroinflammation and neurotoxicity ${ }^{(24)}$. A research on HAND neuropahogenesis demonstrated that HIV exerts its neurovirulence not only by the direct neurotoxic effects of HIV-encoded proteins (Tat, Vpr and gp120), but also by stimulating a cascade of inflammatory substances released by activated or infected cells (macrophages, microglia, astrocytes) ${ }^{(25)}$. These are interesting findings because they indicate that the presence of the virus, and not the viral load magnitude itself, is more important to trigger and mantain the neurological injury. In another study, authors reported evidence of neuroinflammation in autopsy tissues from HIV+ patients with activation of microglia and astrocytes, even in the absense of HIV tissue detection by in situ hybridization technique. This continuous inflamatory cascade leads to neuronal injury, even though neurons are not infected by the HIV. These findings support the notion that inflamation, besides virus production in the brain, explains most of the HAND pathogenesis ${ }^{(26)}$.

In the present study, the mean time from HIV diagnosis to medical follow-up was longer in group 2 ( $p=0.04$ ), suggesting that patients in this group were at higher risk of developing HAND because they were exposed to HIV neuropathogenesis (i.e., neurotoxicity and neuroinflammation) for a longer period ${ }^{(24)}$.

Although patients in group 2 were diagnosed with HAND (IHDS $<10$ ), in the present study, none of them had a clinical diagnosis of dementia. This is an important finding since the early detection of HIV, engagement in care and screening for HAND can minimize chronic neurocognitive sequelae and increase long-term adherence to therapy ${ }^{(3,27)}$.

One of the limitations of the present study is the cross-sectional design, which poses difficulty in casuality inference. In addition, neuroimaging and CSF studies, for ruling out possible diagnoses that could interfere in the IHDS score interpretation, such as neuroaxis infections and neoplasm, were not carried out. The exclusion criteria adopted, which led to the withdrawal of eight patients, were applied to minimize these possible confounding factors. 


\section{CONCLUSION}

The use of neuropsychological assessement tests is an important tool for the early diagnosis of neurocognitive disorders in PLHA. IHDS application demonstrated a high frequency of neurocognitive deficit in the current study population and two variables were possibly associated with this occurrence: age and time from HIV diagnosis to medical follow-up.

\section{REFERENCES}

1. World Health Organization - WHO. Global Health Observatory (GHO) data about HIV/AIDS. Who; 2015 [accessed on 2015 Apr 26]. Available from: http:// www.who.int/gho/hiv/en/

2. Ministério da Saúde (BR), Secretaria de Vigilância em Saúde, Departamento de DST, Aids e Hepatites Virais. Boletim epidemiológico HIV/Aids. Brasília: Ministério da Saúde; 2014.

3. Tedaldi EM, Minniti NL, Fischer T. HIV-associated neurocognitive disorders: the relationship of HIV infection with physical and social comorbidities. Biomed Res Int. 2015;2015:641913.

4. Letendre SL, Ellis RJ, Everall I, Ances B, Bharti A, McCutchan JA. Neurologic complications of HIV disease and their treatment. Top HIV Med. 2009;17(2):46-56.

5. Singer EJ, Sueiras MV, Commins D, Levin EA. Neurologic presentation of AIDS. Neurol Clin. 2010;28(1):253-7.

6. Ganasen KA, Fincham D, Smit J, Seedat S, Stein D. Utility of the HIV Dementia Scale (HDS) in identifying HIV dementia in a South African sample. J Neurol Sci. 2008;269(1-2):62-4.

7. MCarthur JC. HIV dementia: an evolving disease. J Neuroimmunol. 2004;157(1-2):3-10.

8. Ho EL, Jay CA. Altered mental status in HIV: infected patients. Emergency Medicine Clinics of North America. 2010;28(2):311-23.

9. MCarthur JC, Hoover DR, Bacellar H, Miller EN, Cohen BA, Becker JT, et al. Dementia in Aids patients: incidence and risk factors. Multicenter AIDS Cohort Study. Neurology. 1993;43(11):2245-52.

10. Fernandes Filho SMM, Melo HRL. Frequency and risk factors for HIV associated neurocognitive disorder and depression in older individuals with HIV in northeastern Brazil. International Psychogeriatrics. 2012;24(10):1648-55.
11. Sacktor NC, Wong M, Nakasujja N, Skolasky RL, Selnes OA, Musisi S, et al. The International HIV Dementia Scale: a new rapid screening test for HIV dementia. AIDS. 2005;19(13):1367-74.

12. Lyon ME, MCCarter R, D'Angelo LJ. Detecting HIV associated neurocognitive disorders in adolescentes: what is the best screening tool? Journal of adolescent health. 2009;44(2):133-5.

13. Rodrigues RA, Oliveira RL, Grinsztejn B, Silva MTT. Validity of the International HIV Dementia Scale in Brazil. Arq Neuropsiquiatr. 2013;71(6):376-9.

14. Grant I, Franklin JR. DR, Deutsch R, Woods SP, Vaida F, Ellis RJ, et al. Neurology. 2014;82:2055-2062.

15. Heaton RK, Clifford D, Franklin DR, Woods SP, Ake C, Vaida F, et al. HIV-associated neurocognitive disorders persist in the era of potent antiretroviral therapy: CHARTER Study. Neurology. 2010;75(23):2087-96.

16. Clifford DB, Ances BM. HIV-associated neurocognitive disorder. Lancet Infect Dis. 2013;13(11):976-86.

17. Oliveira MF, Murrel B, Pérez-Santiago J, Vargas M, Ellis RJ, Letendre S, et al. Circulating HIV DNA correlates with neurocognitive impairment in older HIV-infected adults on suppressive ART. Sci Rep. 2015;5:17094.

18. Rao VR, Ruiz AP, Prasad VR. Viral and cellular factors underlying neuropathogenesis in HIV associated neurocognitive disorders (HAND). AIDS Res Ther. 2014;11:13.

19. Ellis RJ, Badiee J, Vaida F, Letendre S, Heaton RK, Clifford D, et al. CD4 nadir is a predictor of HIV neurocognitive impairment in the era of combination antiretroviral therapy. AIDS. 2011;25(14):1747-51.

20. Zhang Y, Qiao L, Ding W, Wei F, Zhao Q, Wang $X$, et al. An initial screening for HIV-associated neurocognitive disorders of HIV-1 infected patients in China. J Neurovirol. 2012;18(2):120-6.

21. Simioni S, Cavassini M, Annoni J, Abraham AR, Bourquin I, Schiffer V, et al. Cognitive dysfunction in HIV patients despite long-standing suppression of viremia. AIDS. 2010;24(9):1243-50.

22. Calcagno A, Simiele M, Alberione MC, Bracchi M, Marinaro L, Ecclesia S, et al. Cerebrospinal fluid inhibitory quotients of antiretroviral drugs in HIVinfected patients are associated with compartmental viral control. Clin Infect Dis. 2015;60(2):311-7.

23. Bryant AK, Ellis RJ, Umlauf A, Gouaux B, Soontornniyomkij V, Letendre SL, et al. 
Antiretroviral therapy reduces neurodegeneration in human immunodeficiency virus infection AIDS. 2015;29(3):323-30.

24. Zayyad Z, Spudich S. Neuropathogenesis of HIV: from initial neuroinvasion to HIV Associated Neurocognitive Disorder (HAND). Curr HIV/AIDS Rep. 2015;12(1):16-24.

25. Boisse' L, Gill MJ, Power C. HIV infection of the Central Nervous System: clinical features and neuropathogenesis. Neurol Clin. 2008;26(3):799-819.

26. Tavazzi E, Morrison D, Sullivan P, Morgello S, Fischer T. Brain inflammation is a common feature of HIVinfected patients without HIV encephalitis or productive brain infection. Curr HIV Res. 2014;12(2):97-110.

27. Kamminga J, Cysique LA, Lu G, Batchelor J, Brew BJ. Validity of cognitive screens for HIV-associated neurocognitive disorder: a systematic review and an informed screen selection guide. Curr HIV/AIDS Rep. 2013;10(4):342-55.

\section{First author's address:}

Lara Gurgel Fernandes Távora

Universidade de Fortaleza - UNIFOR

Curso de Medicina

Rua Desembargador Floriano Benevides Magalhães, 221

$-3^{\circ}$ andar

Bairro: Edson Queiroz

CEP: 60.811-690 - Fortaleza - CE - Brazil

E-mail: laratavora@gmail.com

\section{Mailing address:}

Jeová Keny de Baima Colares

Universidade de Fortaleza - UNIFOR

Curso de Medicina

Rua: Desembargador Floriano Benevides Magalhães, 221-

$3^{\circ}$ andar

Bairro: Edson Queiroz

CEP: 60.811-690 - Fortaleza - CE - Brazil

E-mail: kenycolares@gmail.com 